Revista Bioética

Print version ISSN 1983-8042 On-line version ISSN 1983-8034

Rev. Bioét. vol.27 no.2 Brasília Abr./Jun. 2019

Doi: 10.1590/1983-80422019272317

\title{
PESQUISA
}

\section{Teaching how to deliver bad news: a systematic review}

Nicole Cavalari Camargo ${ }^{1}$, Marcelo Gonçalves de Lima ${ }^{1}$, Elisa Brietzke ${ }^{2}$, Samantha Mucci ${ }^{2}$, Aécio Flávio Teixeira de Góis ${ }^{3}$

1. Departamento de Medicina, Universidade Federal de São Paulo (Unifesp), São Paulo/SP, Brasil. 2. Programa Psiquiatria e Psicologia Médica, Departamento de Psiquiatria, Universidade Federal de São Paulo (Unifesp), São Paulo/SP, Brasil. 3. Programa de Medicina de Urgência e Medicina baseada em evidências, Departamento de Medicina, Unifesp, São Paulo/SP, Brasil.

\begin{abstract}
"Bad news", defined as information with huge emotional valence and potential to change personal perspectives, is, by definition, a challenge for physicians. However, the subject is not always taught in medical schools. This systematic literature review compiles all articles regarding communication of bad news after researching in databases for "medical school" and "bad news" in English, Portuguese and Spanish. The criterion was to include articles that elucidated about teaching techniques. From all 313 papers, we included 27 and classified their strategies. Most results showed that mixed strategies are more common and that, in general, the subject is wellreceived and appreciated by students, who reported an improvement in communicative capability after the training. We conclude that all techniques are valid and medical schools should focus on integrating this training in their regular curriculum.

Keywords: Teaching. Education, medical. Truth disclosure. Physician-patient relations. Schools, medical. Methods. Clinical competence.
\end{abstract}

\section{Resumo}

\section{Ensino de comunicação de más notícias: revisão sistemática}

"Má notícia", definida como informação que carrega grande peso emocional e potencial de mudar perspectivas pessoais, é, por definição, desafio para os médicos. Entretanto, nem sempre esse assunto é abordado em faculdades de medicina. Esta revisão sistemática contém todos os artigos encontrados sobre comunicação de más notícias em bases de dados por "medical school" e "bad news" em inglês, português e espanhol. O critério de inclusão abrangia artigos que elucidavam técnicas de ensino. De todos os 313 artigos, 27 foram incluídos, tendo suas estratégias classificadas. A maioria dos resultados mostrou que as estratégias mistas são mais comuns e que, em geral, o tema é bem aceito e valorizado pelos estudantes, que afirmam melhora na capacidade comunicativa depois do treinamento. Conclui-se que todas as técnicas são válidas e que as faculdades de medicina devem focar em integrar esse treinamento no currículo regular.

Palavras-chave: Ensino. Educação médica. Revelação da verdade. Relações médico-paciente. Faculdades de medicina. Métodos. Competência clínica.

\section{Resumen}

\section{La enseñanza de cómo dar malas noticias: una revisión sistemática}

"Mala noticia", definida como una información que conlleva un gran peso emocional y tiene el potencial de cambiar las perspectivas personales; constituye un desafío para los médicos. Sin embargo, este tema no siempre es enseñado en las facultades de medicina. Esta revisión sistemática de la literatura compila todos los artículos encontrados sobre la comunicación de malas noticias luego de buscar "medical school" y "bad news", en inglés, portugués y español, en bases de datos. El criterio empleado fue incluir artículos que tratasen sobre técnicas de enseñanza. De los 313 artículos, incluimos 27 y clasificamos sus estrategias. La mayoría de los resultados mostró que las estrategias mixtas son las más comunes y que, en general, el tema es bien recibido y valorado por los estudiantes, quienes informan que obtienen una mejora en la capacidad comunicativa luego de la formación. Concluimos que todas estas técnicas son válidas y que las facultades de medicina deben enfocarse en integrar esta capacitación en su currículo regular.

Palabras clave: Enseñanza. Educación médica. Revelación de la verdad. Relaciones médico-paciente. Facultades de medicina. Métodos. Competencia clínica.

Declaram não haver conflito de interesse. 
"Bad news" is defined as information that carries huge emotional valence and has the potential to change someone's life and perspective ${ }^{1}$. Examples in medical context include a family loss, a limb amputation, the diagnosis of a degenerative disease, cancer, AIDS and others. They are, by definition, hard to tell and hard to hear: from a philosophical perspective, they can be the words that makes someone's dreams shatter and fall to the ground.

Physicians and other health professionals may face this situation on a daily basis, which does not mean they know how to handle it. What makes Breaking Bad News (BBN) so difficult is that it confronts feelings from both sides of the communication: the patient or the family, who has to deal with the sadness and despair of the information, and the professional, who has to deal with his or her self-confidence, because they must be capable of dealing with their own feelings as well as with the listener's reaction. Besides, loss can be seen, by the physician, as a failure. In addition, research points out that a lot of doctors are still incapable of delivering bad news or even communicating with the family ${ }^{2-5}$ and they struggle to understand how to do it ${ }^{5-7}$, experiencing fear and anxiety about the subject, with physical effects, such as an increase in heart rate ${ }^{8}$.

Also, many of them, when communicating, are incapable of showing their own emotions or expressing empathy ${ }^{4}$. This practice reflects on how students learn communication from observing attending physicians. $A$ regular students' complaint is the lack of role models for bad news communication ${ }^{9}$. On the other hand, results from several researches show that students are willing to learn more about communication skills and that educational approaches are usually well-received $^{9,10}$.

In addition, the impact of poor communication involves serious psychological distress to patients and family members ${ }^{11}$. Moreover, it makes doctors distant from patients, which means they become less able to bond with people and to create a harmonious doctor-patient relationship.

More complicated than that is the notion that communication is an individual expression of culture and social patterns ${ }^{12}$ : In countries where doctor-patient relationships are not built in a hierarchical structure, the dialogue is easier. In countries where doctors tend to monopolize information and the relation is not symmetric, hearing bad news is harder for the family or patient, because of the distance and difficulty to express their feelings ${ }^{13}$. On the other hand, a model where a patient has the power to decide his or her health is proven and seems to be the most adequate ${ }^{13}$.
In this context, the creation of protocols became a structured and relatively easy way to communicate bad news. There are a few protocols, like Spikes (Settings, Patient's perception, Invitation, Knowledge, Explore/Empathy, Strategy/Summary) and $A B C D E$ (Advance preparation; Build a therapeutic environment/relationship; Communicate well; Deal with patient and family reactions; Encourage and validate emotions) and both of them have a small introduction before the news, the news itself, and a time for patient and family reactions.

Nevertheless, not all medical schools teach communication or empathy $7,14,15$, even though those are not concepts acquired spontaneously. Considering the importance of breaking bad news in doctors' daily routine, teaching techniques are a major subject and should be the focus of medical education, preparing medical students to be more humanized graduates.

In this scenario, evidence-based studies suggest communication skills can be taught ${ }^{16-22}$ and a better physician-patient relationship makes patients feel better ${ }^{22-26}$, increases treatment adherence, improves pain management and the prognosis of chronic diseases, and decreases symptoms. In addition, when the physician communicates better, he feels more confident, there are less medical errors and the likelihood of patients to claim malpractice is reduced $^{22-27}$. There is also evidence indicating that, without training, skills in breaking bad news rarely get better with experience ${ }^{8}$.

Considering the scenario in which doctors struggle to deliver bad news and patients suffer with communication failure, teaching techniques and learning methods became key for successful physicians who are able to be empathetic. Nevertheless, not all medical schools include the subject in curricula, even though those are not concepts acquired spontaneously. Hence, the present systematic review compiles the works that brings teaching methods on how to deliver bad news as the main subject. Also, it aims to highlight the importance of the topic and to encourage medical schools to discuss the importance of communication in doctor-physician relationships.

\section{Methodology}

We conducted a search in SciELO, PubMed, the Cochrane Library and Lilacs/BVS using the terms "bad news and medical school" and their corresponding terms in spanish and portuguese. The word "and" was used in the search box or in the option box to correlate terms. We found 240 articles 
in PubMed, 3 in SciELO, 3 in the Cochrane Library and 67 in Lilacs/BVS. Our first analysis excluded many papers, the remaining 91 were in PubMed, 1 in SciELO, 1 in Cochrane and 3 in Lilacs/BVS. There were numerous duplicates between Lilacs and PubMed (31). After a further review, there were 23 articles in PubMed, none in Cochrane, 1 in SciELO and 3 in Lilacs that fulfilled our inclusion criteria. All articles were published between 1982 and 2018. A few articles found in this systematic search were used in the introduction and conclusion. The methodology is schematized in Flowchart 1.

286 articles were not included in this review because they did not approach any specific teaching method or technique of teaching how to deliver bad news. That way, articles where BBN was a module or where BBN was evaluated but not treated as the main subject were discarded. Reviews and book chapters were not included as well because of our objective to use primary data, as any systematic review must be.

Flowchart 1. Methodology to include articles

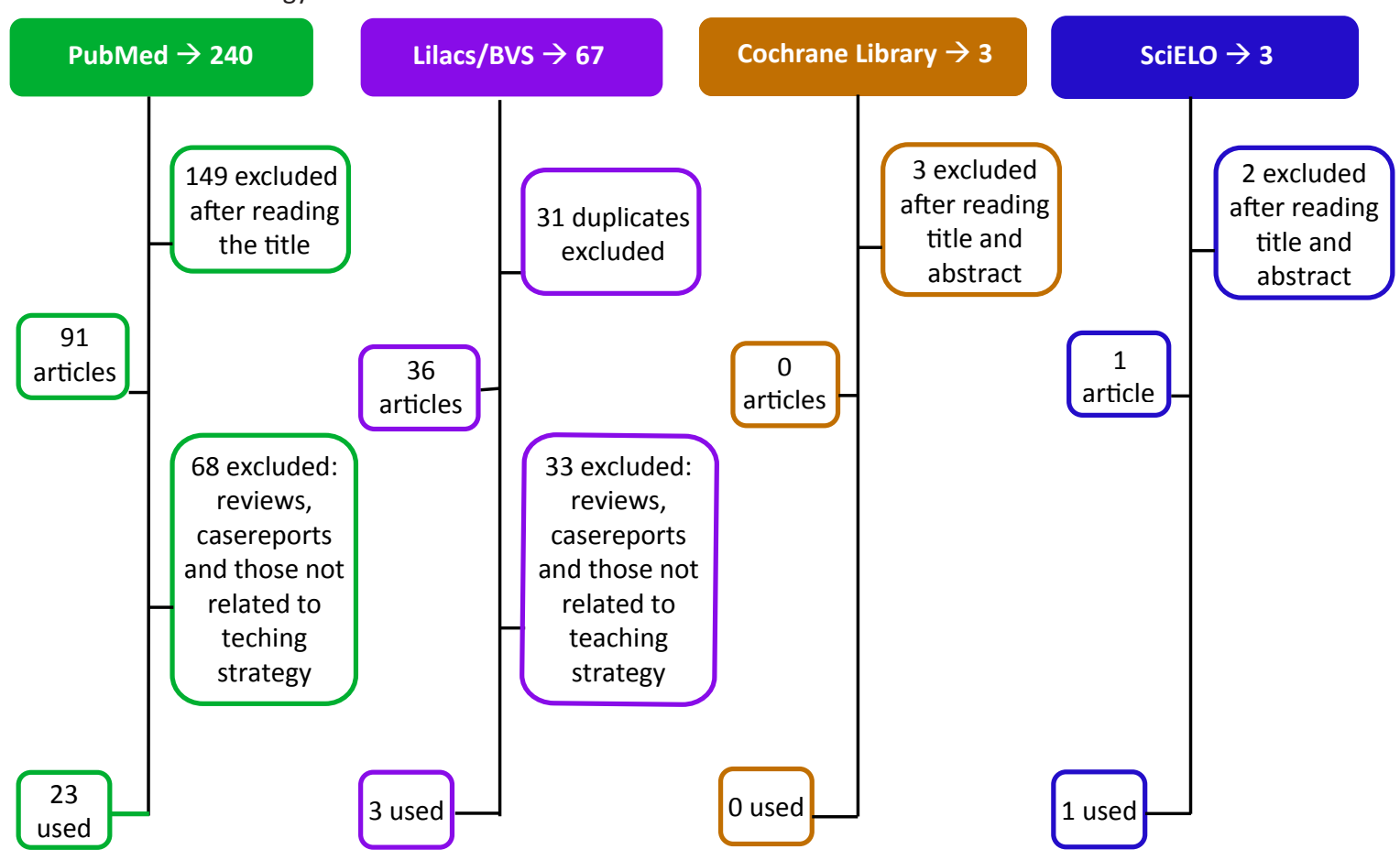

Results

The results of the 27 articles included in this review were summarized in Tables 1, 2 and 3. Regarding the geographic region where the study was developed, we found that $64 \%$ were developed in the United States (USA), 7\% in Brazil, 7\% in Switzerland, and $22 \%$ represented the remaining countries. The most common research participants referred to in the articles reviewed were medical students, representing $46 \%$ of all files. The remaining participants were medical residents and senior doctors, which represent $36 \%$ and $18 \%$ of all articles, respectively.

Moreover, regarding their methodology, it was possible to observe that most articles (96.3\%;
26 articles) adopted a longitudinal design, of which $7.4 \%$ ( 2 articles) were randomized controlled trials. The remaining 1 article, which represents $3.7 \%$ of all articles reviewed, followed the cross-sectional design. When the sample data was observed, we saw that $53.5 \%$ of the articles analyzed had a sample smaller than one hundred subjects, $42.8 \%$ had a sample between one hundred and five hundred subjects, and only $3.7 \%$ had a sample bigger than 1,000 subjects.

The strategies were grouped in 4 categories according to the method or methods adopted. Overall, we divided the approaches in "active learning", which includes role-playing and simulations, and "passive learning", which includes teacher mediated discussions, theory tests, and lectures or classes. It 
is important to declare that this classification was supported by learning theories largely based on neuroscience knowledge.

Neural network, memories' formation and cognition theory are the pillars for propositions naming active learning all teaching techniques that involve the student in reflection and make them build knowledge by themselves, without passive absorption ${ }^{28-30}$. This dichotomy was resolved by mixed strategies and a unique approach with an online forum, which we could not fit in active or passive learning. All of this is synthesized in Table 1, 2 and 3.

Table 1. Articles included in the review, classified as "active learning"

\begin{tabular}{|c|c|c|c|c|c|c|}
\hline \multicolumn{7}{|c|}{ Active learning } \\
\hline Author, year & Country & $\mathbf{n}$ & Population & Design & Instruments & Results \\
\hline $\begin{array}{l}\text { van Weel- } \\
\text { Baumgarten } \\
\text { and } \\
\text { collaborators; } \\
2012^{13}\end{array}$ & $\mathrm{NL}$ & 1260 & $\begin{array}{l}\text { Medical } \\
\text { students }\end{array}$ & Longitudinal & $\begin{array}{l}\text { Basic knowledge in BBN was } \\
\text { evaluated in a questionnaire } \\
\text { before the intervention. } \\
\text { Teaching methods used } \\
\text { web lectures, home } \\
\text { assignments, interactive } \\
\text { DVD, practicing with SPs } \\
\text { with Spikes communication } \\
\text { protocol and ABCDE, in } \\
\text { small groups of various } \\
\text { sizes. Feedback was given to } \\
\text { evaluate development. }\end{array}$ & $\begin{array}{l}\text { Students believe the } \\
\text { correct time to learn about } \\
\text { communication is in year } 3 \\
\text { of medical school }\end{array}$ \\
\hline $\begin{array}{l}\text { Lifchez, } \\
\text { Redett; } \\
2014^{31}\end{array}$ & USA & 17 & $\begin{array}{l}\text { Plastic } \\
\text { residents }\end{array}$ & Longitudinal & $\begin{array}{l}\text { Residents were surveyed } \\
\text { for their prior education in } \\
\text { BBN (Orgel questionnaire) } \\
\text { and took a personality } \\
\text { test (Myers-Briggs) } \\
\text { to understand how it } \\
\text { influences their way to } \\
\text { communicate. }\end{array}$ & $\begin{array}{l}\text { Confidence increased after } \\
\text { training and SP. Those } \\
\text { who evaluated residents' } \\
\text { progress, reported on that } \\
\text { too. The performance in } \\
\text { delivering bad news was } \\
\text { also better after training. }\end{array}$ \\
\hline $\begin{array}{l}\text { Arnold and } \\
\text { collaborators; } \\
2015^{32}\end{array}$ & USA & 38 & $\begin{array}{l}\text { Emergency } \\
\text { residents }\end{array}$ & Longitudinal & $\begin{array}{l}\text { Overview of basic } \\
\text { knowledge followed by } \\
\text { skills training and role- } \\
\text { playing in groups. }\end{array}$ & $\begin{array}{l}\text { After training, residents } \\
\text { showed confidence in } \\
\text { BBN and evaluated their } \\
\text { progress with an increase } \\
\text { of } 23 \% \text {. The WS was rated } \\
\text { as good or excellent. } \\
\text { On a follow up after } 1 \\
\text { month, } 100 \% \text { of them } \\
\text { declared themselves } \\
\text { completely capable of } \\
\text { delivering bad news }\end{array}$ \\
\hline $\begin{array}{l}\text { Greenberg } \\
\text { and } \\
\text { collaborators; } \\
1999^{33}\end{array}$ & USA & 27 & $\begin{array}{l}\text { Pediatric } \\
\text { residents }\end{array}$ & Longitudinal & $\begin{array}{l}\text { Participants were } \\
\text { videotaped and observed } \\
\text { twice while communicating } \\
\text { bad news to a trained SP. } \\
\text { The first observation was } \\
\text { followed by a feedback and } \\
\text { the experience was repeated } \\
\text { about } 4 \text { to } 10 \text { weeks later. } \\
\text { The SP evaluated the } \\
\text { progress in BBN before } \\
\text { and after training, without } \\
\text { knowing when the physician } \\
\text { had training. }\end{array}$ & $\begin{array}{l}\text { Before training, } 79 \% \\
\text { believed they needed } \\
\text { training in BBN and that } \\
\text { they were not capable of } \\
\text { delivering bad news or } \\
\text { counseling parents. } \\
\text { After the intervention, } \\
\text { participants' total score } \\
\text { increased significantly. } \\
\text { Content scores were } \\
\text { correlated positively to } \\
\text { counseling scores, showing } \\
\text { that knowing the theory } \\
\text { helps better practice. }\end{array}$ \\
\hline
\end{tabular}


Table 1. Continuation

\begin{tabular}{|c|c|c|c|c|c|c|}
\hline \multicolumn{7}{|c|}{ Active learning } \\
\hline Author, year & Country & $\mathbf{n}$ & Population & Design & Instruments & Results \\
\hline $\begin{array}{l}\text { Ju and } \\
\text { collaborators; } \\
2014^{34}\end{array}$ & USA & 11 & $\begin{array}{l}\text { Oncology } \\
\text { residents }\end{array}$ & Longitudinal & $\begin{array}{l}\text { Session with SPs and } \\
\text { feedback regarding the } \\
\text { communication }\end{array}$ & $\begin{array}{l}\text { After the feedback, } \\
\text { residents reported } \\
\text { an increase in } \\
\text { communication skills }\end{array}$ \\
\hline $\begin{array}{l}\text { Colletti and } \\
\text { collaborators; } \\
2001^{35}\end{array}$ & USA & 21 & $\begin{array}{l}\text { Medical } \\
\text { students }\end{array}$ & Longitudinal & $\begin{array}{l}\text { 1-hour encounter in which } \\
\text { students should discuss } \\
\text { a new diagnosis of rectal } \\
\text { cancer or a miscarriage. } \\
\text { The student should discuss } \\
\text { diagnosis, treatment } \\
\text { and prognosis. After the } \\
\text { experience, feedback } \\
\text { showed the progress. }\end{array}$ & $\begin{array}{l}\text { Students who had prior } \\
\text { training had better scores } \\
\text { and the scenarios did not } \\
\text { change their performance, } \\
\text { showing that previous } \\
\text { classes are important. }\end{array}$ \\
\hline $\begin{array}{l}\text { Dikici, Yaris, } \\
\text { Cubukcu; } \\
2009^{36}\end{array}$ & $\mathrm{TR}$ & 146 & $\begin{array}{l}\text { Medical } \\
\text { students }\end{array}$ & Longitudinal & $\begin{array}{l}\text { Questionnaire evaluating } \\
\text { effectiveness of the course } \\
\text { and a 4-station OSCE to } \\
\text { assess the impact of the } \\
\text { approach objectively }\end{array}$ & $\begin{array}{l}54 \% \text { of medical students } \\
\text { perceived themselves } \\
\text { as more competent at } \\
\text { handling the task after the } \\
\text { course and most of them } \\
\text { classified the course as } \\
\text { useful. }\end{array}$ \\
\hline $\begin{array}{l}\text { Ramaswamy } \\
\text { and } \\
\text { collaborators; } \\
2014^{37}\end{array}$ & USA & 23 & $\begin{array}{l}\text { Internal } \\
\text { medicine } \\
\text { interns }\end{array}$ & Longitudinal & $\begin{array}{l}\text { The curriculum uses } \\
\text { small-group discussion, } \\
\text { case-based learning, and } \\
\text { repeated practice with role- } \\
\text { playing exercises to engage } \\
\text { learners and develop an } \\
\text { active learning model. This } \\
\text { approach was evaluated } \\
\text { using questionnaires }\end{array}$ & $\begin{array}{l}\text { Three months after the } \\
\text { end of the workshop, } \\
\text { respondents were using } \\
\text { different techniques. } 64 \% \\
\text { of participants felt that } \\
\text { the Spikes mnemonic was } \\
\text { the most helpful skill they } \\
\text { learned in the workshop. } \\
\text { After } 3 \text { months, 38\% of } \\
\text { them were using the Spikes } \\
\text { method, even though } 15 \% \\
\text { of the respondents felt } \\
\text { that Spikes was easy to } \\
\text { use in their interactions } \\
\text { with patients. } 91 \% \text { of } \\
\text { participants believed the } \\
\text { amount of information } \\
\text { disseminated in the } \\
\text { curriculum to be "just right". } \\
81 \% \text { of the participants } \\
\text { felt that the opportunity } \\
\text { for repeated practice was } \\
\text { helpful in enhancing their } \\
\text { communication skills }\end{array}$ \\
\hline $\begin{array}{l}\text { Vail and } \\
\text { collaborators; } \\
2011^{38}\end{array}$ & UK & 285 & $\begin{array}{l}\text { Physicians } \\
\text { from } 22 \\
\text { different } \\
\text { specialties }\end{array}$ & Longitudinal & $\begin{array}{l}\text { BBN scenarios, evaluating } \\
\text { capability to communicate } \\
\text { according to different } \\
\text { specialties }\end{array}$ & $\begin{array}{l}\text { Consultants mainly } \\
\text { focused upon providing } \\
\text { biomedical information } \\
\text { and did not discuss life- } \\
\text { style and psychosocial } \\
\text { issues frequently. These } \\
\text { approaches are not related } \\
\text { to doctor gender, specialty, } \\
\text { place of qualification or age. }\end{array}$ \\
\hline
\end{tabular}

n: sample number; USA: United States of America; NL: Netherlands; UK: United Kingdom; TR: Turkey; SP: Standardized Patients; BBN: Breaking Bad News; WS: Workshop; Spikes: Oncology/Bad news communication protocol ("S=setting up; P=perception; I=invitation; $K=$ knowledge; $E=e m o t i o n s ; S=s t r a t e g y ")$ 


\section{Active learning}

"Active learning" includes techniques where students prioritize to build knowledge by themselves, which means there are few theoretical classes and much more practical exercises, like role-playing, discussions and cases. In this review, nine studies focused on this strategy, synthesized in Table 1. An intervention with plastic surgery residents ${ }^{31}$ from the USA reported that two sessions with a standardized patient were enough to improve communication skills. Between these sessions, there was feedback.

A similar approach was used in the Netherlands ${ }^{13}$, with eight Dutch schools and in four studies in the USA ${ }^{32-35}$, with emergency, pediatric and oncology residents and students. In all these five, learning was based on simulation and feedback. In the one with emergency residents ${ }^{32}$, there was the addition of a card where residents wrote what they had learned, and that card was sent to them one month later to remind them about the experience.

An educational intervention in $2009^{36}$ used several types of active learning, with brainstorming, group discussions and simulations. This rich intervention was not enough to make students feel more confident, considering only $54 \%$ of them felt more capable of handling tasks, but the course was very well-rated. The last similar approach happened in the USA ${ }^{37}$ and worked with internal medicine interns, who participated in group discussions, roleplaying and exercises. Questionnaires evaluated the experience and interns said the experience was helpful and the Spikes protocol was a good mnemonic. In Vail and collaborators ${ }^{38}$, an approach described a simulation with several medical specialties and the result was not related to that. All these strategies were classified as "active learning" because they involved little or no passive instructions and teacher mediated discussions.

\section{Mixed approaches}

"Mixed approaches" include techniques where both practical and theoretical exercises are valued. In this review, they contribute with most of approaches, totaling fourteen articles, synthetized in Table 2 . The most recent is a Brazilian study evaluating a training conducted with perinatology residents ${ }^{39}$. In this study, there was a first encounter with a simulated patient, followed by feedback that reported students' performance. After that, residents were allocated into two groups: control and intervention.

The intervention group received sessions about Spikes communication protocol. These sessions happened in groups, pairs or individually and the residents could identify what could be improved in their behavior from the first encounter. After this training, all residents had a second conversation with a standardized patient. Results showed that the second encounter was more successful than the first, meaning experience has a positive impact in BBN. There was no significant difference between the control and intervention groups, but this result may be limited by the small sample size $(n=61)$. The initiative was well-rated by residents and classified as effective learning.

In a recent study from $2017^{40}$, anesthesiology residents were evaluated by immersive situations in simulations and had a following teaching intervention with simulated patients (SP) to contrast their performances in BBN. They rated themselves as more capable after the training. In a program with nephrology fellows ${ }^{41}$, there was theoretical training and a simulation, with evaluation pre and postworkshop, which showed fellows felt well prepared because of the experience.

An intervention with more theoretical hours was made in German ${ }^{42}$ and taught medical students about communication and physician-patient relationships, using videos, clinical cases, roleplaying and exam preparation. This approach used different strategies and had 267 participants. Results showed students value communication teaching and feel more confident after training.

Other mixed strategies ${ }^{21,22,42-47}$ including brief lectures, discussions and simulations were described as important and effective, resulting in more confidence and proficiency in breaking bad news. In Abel and collaborators ${ }^{43}$, there is a point emphasizing that the multi-professional group proved to be positive to palliative care and education. Sombra Neto and collaborators ${ }^{45}$, results were not only favorable for teaching communication, but showed students had excellent scores after the training. In Skye and collaborators ${ }^{48}$, a strategy very similar to active learning was complemented with home exercises and questionnaires, and also had a positive result, with a $94 \%$ intervention approval.

A mixed strategy used in the USA in 2016 and reported by Parikh and collaborators ${ }^{49}$ questions if those interventions are recalled by students. With 105 surgical interns, the study showed that the simulation training had an effect over at least 1 year after the experience. Also, an initiative with a numerous participants $(n=1455)$ was made at Yale $^{50}$, with BBN teaching and role-playing. However, 
the study was limited because there was not a questionnaire to evaluate the experience.

Lastly, an interesting approach divided internal medicine residents into control and intervention groups. The intervention group received training with practical and theoretical classes. The final result was that trained residents had better performance in delivering bad news and reported feeling more confident doing it. The evaluators also saw a more empathetic approach ${ }^{51}$.

Table 2. Articles included in the review, classified as "mixed strategies"

\begin{tabular}{|c|c|c|c|c|c|c|}
\hline \multicolumn{7}{|c|}{ Mixed strategies } \\
\hline Author, year & Country & n & Population & Design & Instruments & Results \\
\hline $\begin{array}{l}\text { Fujimori and } \\
\text { collaborators; } \\
2014^{21} \text {; } \\
\text { Fujimori and } \\
\text { collaborators; } \\
2014^{22}\end{array}$ & $J P$ & $\begin{array}{c}30 \\
\text { oncologists } \\
\text { and } 580 \\
\text { patients }\end{array}$ & $\begin{array}{c}\text { Oncologists e } \\
\text { patients }\end{array}$ & Longitudinal & $\begin{array}{l}\text { Questionnaires } \\
\text { evaluating knowledge } \\
\text { were given to } \\
\text { oncologists. A group } \\
\text { of oncologists } \\
\text { attended workshop } \\
\text { training on } \\
\text { communication, while } \\
\text { another group did } \\
\text { not receive training. } \\
\text { Follow up with } \\
\text { patients took place. }\end{array}$ & $\begin{array}{l}\text { Simulation with } \\
\text { patients was taped and } \\
\text { evaluated by patients } \\
\text { on an 11-point scale. } \\
\text { Oncologists who } \\
\text { received training in } \\
\text { BBN had better results } \\
\text { than those who did } \\
\text { not. The workshop } \\
\text { was well evaluated by } \\
\text { oncologists and they } \\
\text { felt more confident } \\
\text { in BBN after the } \\
\text { intervention. }\end{array}$ \\
\hline $\begin{array}{l}\text { Setubal and } \\
\text { collaborators; } \\
2018^{39}\end{array}$ & $B R$ & 61 & $\begin{array}{c}\text { Perinatology } \\
\text { residents }\end{array}$ & Longitudinal & $\begin{array}{l}\text { Residents met a SP } \\
\text { and were allocated } \\
\text { to control and } \\
\text { intervention (Spikes) } \\
\text { groups. After the } \\
\text { intervention, both } \\
\text { groups met a SP again. }\end{array}$ & $\begin{array}{l}\text { There was no difference } \\
\text { between intervention } \\
\text { and control groups. The } \\
\text { second session with the } \\
\text { SP was better, showing } \\
\text { practice leads to } \\
\text { success. The experience } \\
\text { was well-rated. }\end{array}$ \\
\hline $\begin{array}{l}\text { Karam and } \\
\text { collaborators; } \\
2017^{40}\end{array}$ & USA & 16 & $\begin{array}{l}\text { Anesthesiology } \\
\text { residents }\end{array}$ & Longitudinal & $\begin{array}{l}\text { The BBN experiences } \\
\text { with GRIEV_ING } \\
\text { check-list were } \\
\text { obtained using } \\
\text { simulators with } \\
\text { a high fidelity } \\
\text { to immersive } \\
\text { experiences. } \\
\text { After that, role- } \\
\text { playing with SP } \\
\text { complemented the } \\
\text { experiences. }\end{array}$ & $\begin{array}{l}\text { Performance in case } 1 \\
\text { did not vary in relation } \\
\text { to the year of training. } \\
\text { Pre-test scores were } \\
\text { lower than post-test } \\
\text { scores on the GRIEV__ } \\
\text { ING check-list. } \\
\text { Also, before the } \\
\text { workshop, 52\% rated } \\
\text { their competence in } \\
\text { BBN as good and very } \\
\text { good. This number } \\
\text { increased to 93\% after } \\
\text { the workshop, with an } \\
\text { increase in confidence } \\
\text { as well. }\end{array}$ \\
\hline $\begin{array}{l}\text { Cohen and } \\
\text { collaborators; } \\
2016^{41}\end{array}$ & USA & 26 & $\begin{array}{l}\text { Nephrology } \\
\text { fellows }\end{array}$ & Longitudinal & $\begin{array}{l}\text { Fellows were } \\
\text { assigned to three } \\
\text { cases about } \\
\text { treatment, how to } \\
\text { break bad news and } \\
\text { to discuss prognosis }\end{array}$ & $\begin{array}{l}\text { Respondents affirmed } \\
\text { their development went } \\
\text { from "not prepared" to } \\
\text { "very well prepared". } \\
\text { Also, they rated the } \\
\text { course as excellent. }\end{array}$ \\
\hline
\end{tabular}


Table 2. Continuation

\begin{tabular}{|c|c|c|c|c|c|c|}
\hline \multicolumn{7}{|c|}{ Mixed strategies } \\
\hline Author, year & Country & $\mathbf{n}$ & Population & Design & Instruments & Results \\
\hline $\begin{array}{l}\text { von Lengerke, } \\
\text { Kursch, Lange; } \\
2011^{42}\end{array}$ & DE & $267(100)$ & $\begin{array}{l}\text { Medical } \\
\text { students }\end{array}$ & Longitudinal & $\begin{array}{l}\text { Students were } \\
\text { assigned to seven } \\
\text { sessions lasting four } \\
\text { hours each, containing } \\
\text { theory about } \\
\text { physician-patient } \\
\text { communication, } \\
\text { practical exercises, } \\
\text { nonverbal } \\
\text { communication, } \\
\text { video-classes, cases, } \\
\text { disclosure of a } \\
\text { diagnosis and role- } \\
\text { playing. }\end{array}$ & $\begin{array}{l}\text { Most students fully } \\
\text { agreed with the } \\
\text { teaching methods } \\
\text { and subjects, } \\
\text { affirming progress in } \\
\text { communication. }\end{array}$ \\
\hline $\begin{array}{l}\text { Abel and } \\
\text { collaborators; } \\
2001^{43}\end{array}$ & UK & 140 & $\begin{array}{l}\text { Senior doctors } \\
\text { and nurses }\end{array}$ & Longitudinal & $\begin{array}{l}\text { A course was } \\
\text { developed for doctors } \\
\text { and nurses with } \\
\text { previous training } \\
\text { in communication. } \\
\text { Areas that needed } \\
\text { improvement were } \\
\text { investigated and } \\
\text { implemented in the } \\
\text { project }\end{array}$ & $\begin{array}{l}\text { They all agreed the } \\
\text { course was important } \\
\text { and most of them } \\
\text { thought BBN was the } \\
\text { most useful part. Also, } \\
\text { there was an increase } \\
\text { in confidence on how } \\
\text { to deliver bad news. }\end{array}$ \\
\hline $\begin{array}{l}\text { Alexander and } \\
\text { collaborators; } \\
2006^{44}\end{array}$ & USA & 56 & $\begin{array}{l}\text { Medical } \\
\text { residents }\end{array}$ & Longitudinal & $\begin{array}{l}\text { 16-hour curriculum } \\
\text { that included } \\
\text { control of pain } \\
\text { and symptoms, } \\
\text { communication skills } \\
\text { (BBN) and ethics. } \\
\text { Groups were divided } \\
\text { into control and } \\
\text { intervention, and } \\
\text { they were evaluated } \\
\text { before and after the } \\
\text { approach. }\end{array}$ & $\begin{array}{l}\text { Both groups had the } \\
\text { same prior training. } \\
\text { After the training, the } \\
\text { intervention group had } \\
\text { much higher scores. }\end{array}$ \\
\hline $\begin{array}{l}\text { Sombra } \\
\text { Neto and } \\
\text { collaborators; } \\
2017^{45}\end{array}$ & $B R$ & 119 & $\begin{array}{l}\text { Medical } \\
\text { students }\end{array}$ & Longitudinal & $\begin{array}{l}\text { Students watched } \\
\text { theoretical } \\
\text { weekly classes } \\
\text { and participated } \\
\text { in practical BBN } \\
\text { simulations, with } \\
\text { simulated patients } \\
\text { and training in pairs }\end{array}$ & $\begin{array}{l}67 \% \text { of students } \\
\text { presented an excellent } \\
\text { score (>90\%), } 7 \% \text { was } \\
\text { considered regular or } \\
\text { bad. } 16 \% \text { concluded the } \\
\text { test with the maximum } \\
\text { score and the lowest } \\
\text { score was } 68 \% \text {. }\end{array}$ \\
\hline $\begin{array}{l}\text { Burn and } \\
\text { collaborators; } \\
2014^{46}\end{array}$ & $\mathrm{CH}$ & 225 & $\begin{array}{l}\text { Medical } \\
\text { students }\end{array}$ & Longitudinal & $\begin{array}{l}\text { In this cohort trial, the } \\
\text { intervention group } \\
\text { received training in } \\
\text { ethics, truth-telling } \\
\text { and BBN. Students } \\
\text { were evaluated } \\
\text { by questionnaires } \\
\text { before and after the } \\
\text { approach. }\end{array}$ & $\begin{array}{l}\text { Students' ethical } \\
\text { attitudes regarding } \\
\text { truth-telling remained } \\
\text { stable, but they } \\
\text { started to feel more } \\
\text { comfortable about } \\
\text { those situations, and } \\
\text { two thirds of students } \\
\text { who did not feel } \\
\text { confident before felt } \\
\text { confident afterwards. }\end{array}$ \\
\hline
\end{tabular}


Table 2. Continuation

\begin{tabular}{|c|c|c|c|c|c|c|}
\hline \multicolumn{7}{|c|}{ Mixed strategies } \\
\hline Author, year & Country & n & Population & Design & Instruments & Results \\
\hline $\begin{array}{l}\text { Hurst and } \\
\text { collaborators; } \\
2015^{47}\end{array}$ & $\mathrm{CH}$ & 225 & $\begin{array}{l}\text { Medical } \\
\text { students }\end{array}$ & Longitudinal & $\begin{array}{l}\text { Students participated } \\
\text { in encounters with } \\
3 \text { simulated patients } \\
\text { and received feedback } \\
\text { to understand their } \\
\text { progress. } \\
\text { Intervention was } \\
\text { composed of a } \\
90 \text {-minute talk with } \\
\text { SP, a 15-minute } \\
\text { ethical discussion } \\
\text { and a 60-minute } \\
\text { communication skills } \\
\text { practice }\end{array}$ & $\begin{array}{l}\text { Students ethical } \\
\text { attitudes remained } \\
\text { stable. They developed } \\
\text { new skills following } \\
\text { the intervention, } \\
\text { and increased their } \\
\text { awareness of the } \\
\text { difficulties and } \\
\text { challenges raised } \\
\text { by BBN situations, } \\
\text { allowing them } \\
\text { to resolve their } \\
\text { weaknesses }\end{array}$ \\
\hline $\begin{array}{l}\text { Skye and } \\
\text { collaborators; } \\
2014^{48}\end{array}$ & USA & 451 & $\begin{array}{l}\text { Medical } \\
\text { students }\end{array}$ & Longitudinal & $\begin{array}{l}\text { Students watched a } \\
\text { simulation about a } \\
\text { woman with colon } \\
\text { cancer. After that, } \\
\text { they discussed } \\
\text { empathy, doctors, } \\
\text { gender, dynamics, } \\
\text { power and support } \\
\end{array}$ & $\begin{array}{l}\text { The intervention was } \\
\text { well received ( } 94 \% \\
\text { agreed or strongly } \\
\text { agreed with the } \\
\text { method). They valued } \\
\text { the strategy. }\end{array}$ \\
\hline $\begin{array}{l}\text { Parikh and } \\
\text { collaborators; } \\
2017^{49}\end{array}$ & USA & 105 & $\begin{array}{l}\text { Medical } \\
\text { students }\end{array}$ & Longitudinal & $\begin{array}{l}\text { Questionnaires } \\
\text { about how } \\
\text { participants rated the } \\
\text { intervention which } \\
\text { was composed of } \\
\text { discussions and role- } \\
\text { playing, and whether } \\
\text { they retained the } \\
\text { training after } 1 \text { year }\end{array}$ & $\begin{array}{l}\text { Students rated the } \\
\text { intervention as } \\
\text { essential for medical } \\
\text { education and affirmed } \\
\text { feeling more capable } \\
\text { of discussing life and } \\
\text { death with patients. } \\
\text { Results were evaluated } \\
\text { after } 1 \text { year (12-24 } \\
\text { months) }\end{array}$ \\
\hline $\begin{array}{l}\text { Ellman, Fortin; } \\
2012^{50}\end{array}$ & USA & 1455 & $\begin{array}{l}\text { Medical } \\
\text { students }\end{array}$ & $\begin{array}{l}\text { Cross- } \\
\text { sectional }\end{array}$ & $\begin{array}{l}\text { Communicating } \\
\text { Difficult News } \\
\text { Workshop and Ward- } \\
\text { Based End-of-Life Care } \\
\text { Assignment, which } \\
\text { was developed at Yale } \\
\text { Medical School. }\end{array}$ & Not evaluated \\
\hline $\begin{array}{l}\text { Szmuilowicz } \\
\text { and } \\
\text { collaborators; } \\
2010^{51}\end{array}$ & USA & 56 & $\begin{array}{l}\text { Internal } \\
\text { medicine } \\
\text { residents }\end{array}$ & Longitudinal & $\begin{array}{l}\text { Residents were } \\
\text { assigned to a control } \\
\text { or intervention } \\
\text { group, which was } \\
\text { addressed with } \\
\text { a combination of } \\
\text { teaching styles and } \\
\text { skills practice }\end{array}$ & $\begin{array}{l}\text { Residents in the } \\
\text { intervention } \\
\text { group showed an } \\
\text { improvement in } \\
\text { communication } \\
\text { (treatment options and } \\
\text { prognosis) and ability } \\
\text { to show emotional } \\
\text { support. Also, they felt } \\
\text { more confident. These } \\
\text { changes were not seen } \\
\text { in the control group. }\end{array}$ \\
\hline
\end{tabular}

n: sample number; USA: United States of America; UK: United Kingdom; GRIEV_ING: Death notification protocol ("G= Gather; $R=$ Resources; I=Identify; E= Educate; V=Verify; I=Inquire; $N=$ Nuts and Bolts and G=Give"); SP: Standardized Patients; BBN: Breaking Bad News; JP: Japan; CH: China; BR: Brazil; WS: Workshop 


\section{Passive Learning}

Only three of twenty-seven (11\%) papers used approaches based on "passive learning" 52-54, and they are included in Table 3. In Brown and collaborators ${ }^{52}$, 2014, 109 radiology trainees were evaluated after a workshop with mediateddiscussions, lectures and media content. They rated the initiative as useful and reported more confidence and lower stress regarding the subject after the intervention. In Levi and Green ${ }^{53}$ 2003, 20 residents approved a more humanized residency curriculum, with more discussions, poetry, talks about medical errors, difficult patients and how to deal with them and the purpose of medicine. In Coutinho and Ramessur ${ }^{54}$, the study was limited by the low percentage of the initiative's respondents: only $21 \%$ of 260 students evaluated the effectiveness of a lecture on how to deliver bad news. The result was that $19.3 \%$ thought the lecture was adequate and should be included in the normal curriculum, but they believed the initiative would be more valuable if there was a practical activity.

\section{Online training}

Another teaching technique described in one article was the creation of an online forum that encouraged students to talk about medicine's "difficult talks". This approach is also synthetized in Table 3. The forum was named the Difficult Conversations Online Forum and was tested with 315 medical students ${ }^{55}$ in the USA. The forum permitted students to respond to each other in order to stimulate reflection.

They had to submit at least one post (about patients, their own emotions or a family's perspective) and could respond to any colleague. They concluded, after use, that the forum was an important implementation and most of them thought the initiative very useful, allowing them to plan conversations and reactions when talking to patients and loved ones.

Table 3. Articles included in the review, classified as "passive learning and online forum"

\begin{tabular}{|c|c|c|c|c|c|c|}
\hline \multicolumn{7}{|c|}{ Passive learning and online forum } \\
\hline Author, year & Country & $\mathbf{n}$ & Population & Design & Instruments & Results \\
\hline $\begin{array}{l}\text { Brown and } \\
\text { collaborators; } \\
2014^{52}\end{array}$ & USA & 109 & $\begin{array}{l}\text { Radiology } \\
\text { residents }\end{array}$ & Longitudinal & $\begin{array}{l}\text { Questionnaires applied } \\
\text { immediately before and } \\
\text { after communication } \\
\text { workshop, containing } \\
\text { mediated discussions, } \\
\text { lectures and media content }\end{array}$ & $\begin{array}{l}\text { After completing the } \\
\text { workshop, more trainees } \\
\text { reported feeling comfortable } \\
\text { when communicating bad } \\
\text { news to patients. } \\
\text { They desired additional } \\
\text { communication training on } \\
\text { error disclosure, general } \\
\text { communication and } \\
\text { radiation risks }\end{array}$ \\
\hline $\begin{array}{l}\text { Levi, Green; } \\
2003^{53}\end{array}$ & USA & 20 & $\begin{array}{l}\text { Medical } \\
\text { residents }\end{array}$ & Longitudinal & $\begin{array}{l}\text { There were didactic lectures, } \\
\text { discussions, sessions with } \\
\text { poetry and depositions, to } \\
\text { understand how the patient } \\
\text { receives bad news. There } \\
\text { was also a didactic lesson } \\
\text { about effective ways of } \\
\text { communicating bad news }\end{array}$ & $\begin{array}{l}\text { Residents enjoyed the } \\
\text { retreat and valued it as a } \\
\text { professional experience. } \\
\text { They appreciated it and } \\
\text { rethought the purpose of } \\
\text { becoming a physician and } \\
\text { dealing with patients }\end{array}$ \\
\hline $\begin{array}{l}\text { Coutinho, } \\
\text { Ramessur; } \\
2016^{54}\end{array}$ & PT & 260 & $\begin{array}{l}\text { Medical } \\
\text { students }\end{array}$ & $\begin{array}{l}\text { Cross- } \\
\text { sectional }\end{array}$ & $\begin{array}{l}\text { 45-minute lecture that aimed } \\
\text { to provide basic theory on } \\
\text { how to deliver bad news (for } \\
\text { example, Spikes). }\end{array}$ & $\begin{array}{l}21 \% \text { responded to the } \\
\text { survey. } 92 \% \text { of them felt the } \\
\text { subject should be included } \\
\text { in the normal curriculum. } \\
83 \% \text { of them felt the lecture } \\
\text { was appropriate and } \\
\text { effective, efficient for the } \\
\text { duration. Nevertheless, they } \\
\text { thought that only lectures } \\
\text { were not enough and } \\
\text { practical activities would be } \\
\text { useful too. }\end{array}$ \\
\hline
\end{tabular}


Table 3. Continuation

\begin{tabular}{|c|c|c|c|c|c|c|}
\hline \multicolumn{7}{|c|}{ Passive learning and online forum } \\
\hline Author, year & Country & $\mathbf{n}$ & Population & Design & Instruments & Results \\
\hline $\begin{array}{l}\text { Makoul and } \\
\text { collaborators; } \\
2010^{55}\end{array}$ & USA & 315 & $\begin{array}{l}\text { Medical } \\
\text { students }\end{array}$ & Longitudinal & $\begin{array}{l}\text { The DC Online Forum uses } \\
\text { virtual dialectic design. It } \\
\text { makes possible for students } \\
\text { to respond to each other } \\
\text { and to reflect. Also, it can be } \\
\text { accessed at different times } \\
\text { and locations }\end{array}$ & $\begin{array}{l}\text { Students submitted } \\
\text { stories about patients } \\
\text { and concluded that the } \\
\text { interface was important } \\
\text { and made them more } \\
\text { capable of planning } \\
\text { conversations and } \\
\text { reactions. Also, they } \\
\text { commented about their } \\
\text { experiences in a group with } \\
\text { attendings and said how } \\
\text { much influence they had. }\end{array}$ \\
\hline
\end{tabular}

n: sample number; USA: United States of America; BBN: Breaking Bad News

\section{Discussion}

First of all, we must consider that there is a temporal tendency, nowadays, to talk about medical education and its humanization. That is demonstrated by the larger number of papers we found in the last decade in comparison with the last century, resulting in $96.3 \%$ of the articles. That means we are building a more empathetic medical education and it can only mean a gain for patient care.

Overall, it was possible to find studies involving different teaching strategies for medical students, resident physicians and doctors with several years of clinical practice. The most studied group was medical residents, which represent a first step to real medical practice. Thus, it is very plausible that the motivation and the interest in any kind of intervention would be stronger in this group compared to medical students. The senior doctors, on the other hand, have already been exposed to this task, so it is possible that they could not be considered a priority group to receive the BBN teaching.

Regarding teaching techniques, the most valuable methods seem to be the adoption of mixed strategies because it involves different types of approaches, which is favorable in the process of making memories. It is also consistent with the results of various studies $8,21,22,39-51$. Nevertheless, a direct comparison between different methods cannot offer a definitive conclusion about the subject, because they only suggest but do not definitely demonstrate the best one. It may be because the best method also depends on how the medical curriculum is developed, how lectures are given, how teachers present the topic and how the health system is structured. These variables depend on the country and the culture.

A shared point of several strategies was the presence of feedback ${ }^{13,31-35,39,42,47,48}$, which the students thought was of great value. Moreover, there is evidence that the feedback itself is a form of learning, because it allows students to understand and reflect on their mistakes ${ }^{39}$. Another interesting observation is that seeing interactions in real life (with real patients) is more effective for students to learn ${ }^{50}$. Likewise, scenarios created with a biopsychosocial perspective are more valuable to students ${ }^{42}$, just as knowing the mechanism of the disease and its evolution, when accompanying the family through the process ${ }^{32}$.

In addition, other factors inherent to the personality or psychological functioning of the doctors could be playing a role. One example of this is an interesting Australian study ${ }^{8}$ in which senior doctors with little experience in breaking bad news were exposed to scenarios in which they had to communicate to a standardized patient. In this intervention, they were taught three methods and were free to choose one of them in this encounter. Skin conduction and heart rate were measured to understand the stress associated with communication. In didactic lessons, doctors learnt three ways to break bad news: with a small introduction, directly or with a lot of technical information. The results pointed out that they prefer to talk directly or with a brief introduction and these methods were associated with less stress.

Although useful, the results of this review should be interpreted in light of some limitations. The first one is the small sample size of most studies ${ }^{8,21,22,}$ $31-35,37,39-41,48,50,53$. The smaller sample sizes were 
especially observed in studies with longitudinal design. Other limitations were the absence of practical activities in "passive learning" strategies ${ }^{52,54}$, the lack of a control group ${ }^{40,42}$, and the absence of standardized evaluation after the approach, that would allow us to compare different techniques among the studies. In addition, several studies restricted interventions to only a school or specialty 8,21,22,31-36,39-42,44-47,49-52,54,55. The absence of a long-term follow up was also a common limitation to almost all of them ${ }^{13,39,40,42-52,54}$. The sample size precluded evaluation of subgroups. This would be especially important in light of some data suggesting that learning goals could be better achieved by female students ${ }^{56}$.

An important point to emphasize is the effectiveness in the use of bad news delivery protocols. Three out of four ${ }^{13,37,54}$ studies using Spikes did not use a group without the protocol. That means that the students' performance cannot be compared to those who did not receive any training and the impact of the protocol usage cannot be established. One study ${ }^{39}$ compared two groups: one using the Spikes protocol and another without any checklist to follow, only communicating bad news to SPs. The results showed both groups had similar performances, valuing the experience and feeling more confident to deliver bad news, suggesting that the act itself is important. This limitation was observed in all of this review, where we can see that most of the studies did not use a group without the intervention, which prevented us from concluding which technique is more effective. Also, although studies cited the methods for each approach, the details were not completed elucidated. The difficulty to evaluate the students using a standardized checklist was also a complicating factor to determine the best teaching method.

Another limitation is that there are only two developing countries in the list, Brazil and Turkey, representing only $11.12 \%$ of the reviewed studies. Studies conducted in the USA corresponded to $59.25 \%$ of all articles. Even considering that this information reveals the central role of this country in the production of medical research knowledge, when we discuss aspects that could be strongly influenced by cultural, social and economic contexts, the fact that most studies were conducted in only one geographic region could be problematic.

Finally, it is also important to consider patients' perspective of BBN communication. Patients often regard a conversation with a lot of technical information as an uncaring attitude ${ }^{57}$ and prefer a doctor who is clear, firm and open-minded about options ${ }^{58}$. There is evidence that patients tend to prefer doctors who ask them about how much information they would want to receive and pause so that they could ask questions ${ }^{11,58}$. They believe the doctor must be capable of seeing them as individuals - complex and bearers of emotional structures, different from others - that each has a disease with a particular meaning. Besides, they refer to feeling better if the doctor listens intently to their anxieties and demonstrates caring by recommending other doctors and treatment options, just as they value a doctor who is capable of expressing emotions ${ }^{59}$. It is also perceived as caring when the doctor explains the medical condition in a direct and straightforward way, but without being abrupt, and with verbal and nonverbal communication, responding to emotional cues in an empathetic and respectful way ${ }^{57}$.

One promising avenue to address the individual perspective was the approach used in a study in the University of Chicago ${ }^{17}$, where a general communication program taught BBN taking into account different psychological personalities and how they would prefer to receive bad news. Results were positive but the teaching strategy was not clearly elucidated.

Considering the atmosphere of medical care and the individuality of each patient, it is important to remember that, even though teaching methods and protocols are substantial, physicians must be able to understand and to communicate with every single patient in a unique and proper way, which was also a desire expressed by patients when asked about the subject.

\section{Final considerations}

The results of this review suggest that different techniques could be used to teach BBN to medical students, resident physicians and senior doctors. As much as the mixed approaches are more valuable, all the approaches tested and compiled in this review had positive results. The most important limitations are the small sample sizes, the methodological aspects linked to the selection of research subjects and outcomes assessment, and the small number of studies conducted outside the USA. Our results scientifically support the adoption of integrating training in BBN in the regular curriculum of medical schools, residency programs and medical continued education, as its importance and acceptability was demonstrated in most studies. 


\section{Referências}

1. Buckman R. Breaking bad news: why is it still so difficult? BMJ [Internet]. 1984 [acesso 15 jan 2018];288(6430):1597-9. Disponível: https://bit.ly/2VtlBBS

2. Eggly S, Afonso N, Rojas G, Baker M, Cardozo L, Robertson RS. An assessment of residents' competence in the delivery of bad news to patients. Acad Med [Internet]. 1997 [acesso 15 jan 2018];72(5):397-9. Disponível: https://bit.ly/2JNOc4r

3. Wittenberg-Lyles EM, Goldsmith J, Sanchez-Reilly S, Ragan SL. Communicating a terminal prognosis in a palliative care setting: deficiencies in current communication training protocols. Soc Sci Med [Internet]. 2008 [acesso 15 jan 2018];66(11):2356-65. Disponível: https://bit.ly/30kXuZp

4. Tang WR, Fang JT, Fang CK, Fujimori M. Truth telling in medical practice: students' opinions versus their observations of attending physicians' clinical practice. Psychooncology [Internet]. 2012 [acesso 15 jan 2018];22(7):1605-10. Disponível: https://bit.ly/2Hk7F84

5. Tsai JC, Liu KM, Lee KT, Yen JC, Yen JH, Liu CK et al. Evaluation of the effectiveness of postgraduate general medicine training by objective structured clinical examination: pilot study and reflection on the experiences of Kaohsiung Medical University Hospital. Kaohsiung J Med Sci [Internet]. 2008 [acesso 15 jan 2018];24(12):627-33. Disponível: https://bit.ly/2JKEIKV

6. Monden KR, Gentry L, Cox TR. Delivering bad news to patients. Proc (Bayl Univ Med Center) [Internet]. 2016 [acesso 15 jan 2018];29(1):101-2. Disponível: https://bit.ly/2JC4DLV

7. Rappaport W, Witzke D. Education about death and dying during the clinical years of medical school. Surgery [Internet]. 1993 [acesso 15 jan 2018];113(2):163-5. Disponível: https://bit.ly/30sGcKe

8. Shaw J, Brown R, Dunn S. The impact of delivery style on doctors' experience of stress during simulated bad news consultations. Patient Educ Couns [Internet]. 2015 [acesso 15 jan 2018];98(10):1255-9. Disponível: https://bit.ly/2HtYfHO

9. Afghani B, Besimanto S, Amin A, Shapiro J. Medical students' perspectives on clinical empathy training. Educ Health [Internet]. 2011 [acesso 15 jan 2018];24(1):544. Disponível: https://bit.ly/30iuYrz

10. Supe AN. Interns' perspectives about communicating bad news to patients: a qualitative study. Educ Health [Internet]. 2011 [acesso 15 jan 2018];24(3):541. Disponível: https://bit.ly/2vYyvNS

11. Atasoy BM, Sarikaya O, Kuscu MK, Yondem M, Buyukkara E, Eken EG et al. Students meeting with caregivers of cancer patient: results of an experience-based learning project. J Cancer Educ [Internet]. 2012 [acesso 15 jan 2018];27(4):656-63. Disponível: https://bit.ly/2VnSbVz

12. Mostafazadeh-Bora M, Zarghami A. Breaking and sharing bad news in end of life: the religious and culture matters. J Relig Health [Internet]. 2017 [acesso 15 jan 2018];56(5):1655-7. Disponível: https://bit.ly/2YuBiKN

13. van Weel-Baumgarten EM, Brouwers M, Grosfeld F, Jongen Hermus F, Van Dalen J, Bonke B. Teaching and training in breaking bad news at the Dutch medical schools: a comparison. Med Teach [Internet]. 2012 [acesso 15 jan 2018];34(5):373-81. Disponível: https://bit.ly/30sHd50

14. Ury WA, Berkman CS, Weber CM, Pignotti MG, Leipzig RM. Assessing medical students' training in end-of-life communication: a survey of interns at one urban teaching hospital. Acad Med [Internet]. 2003 [acesso 15 jan 2018];78(5):530-7. Disponível: https://bit.ly/2JliU3n

15. Hebert HD, Butera JN, Castillo J, Mega AE. Are we training our fellows adequately in delivering bad news to patients? A survey of hematology/oncology program directors. J Palliat Med [Internet]. 2009 [acesso 15 jan 2018];12(12):1119-24. Disponível: https://bit.ly/2WKDs8y

16. Hochberg MS, Kalet A, Zabar S, Kachur E, Gillespie C, Berman RS. Can professionalism be taught? Encouraging evidence. Am J Surg [Internet]. 2010 [acesso 15 jan 2018];199(1):86-93. Disponível: https://bit.ly/30hiC2S

17. Ang M. Advanced communication skills: conflict management and persuasion. Acad Med [Internet]. 2002 [acesso 15 jan 2018];77(11):1166. Disponível: https://bit.ly/30gqTUF

18. Vetto JT, Elder NC, Toffler WL, Fields SA. Teaching medical students to give bad news: does formal instruction help? J Cancer Educ [Internet]. 1999 [acesso 15 jan 2018];14(1):13-7. Disponível: https://bit.ly/2W6eAek

19. Lubimir KT, Wen AB. Towards cultural competency in end-of-life communication training. Hawaii Med J [Internet]. 2011 [acesso 15 jan 2018];10(11):239-41. Disponível: https://bit.ly/2JiZyfl

20. Rider EA, Volkan K, Hafler JP. Pediatric residents' perceptions of communication competencies: implications for teaching. Med Teach [Internet]. 2008 [acesso 15 jan 2018];30(7):e208-17. Disponível: https://bit.ly/2HAZlvx

21. Fujimori M, Shirai Y, Asai M, Kubota K, Katsumata N, Uchitomi Y. Effect of communication skills training program for oncologists based on patient preferences for communication when receiving bad news: a randomized controlled trial. J Clin Oncol [Internet]. 2014 [acesso 15 jan 2018];32(20):2166-72. Disponível: https://bit.ly/2Hocl7z

22. Fujimori M, Shirai Y, Asai M, Akizuki N, Katsumata N, Kubota K et al. Development and preliminary evaluation of communication skills training program for oncologists based on patient preferences for communicating bad news. Palliat Support Care [Internet]. 2014 [acesso 15 jan 2018];12(5):37986. Disponível: https://bit.ly/2LI5ukc

23. Mumford E, Schlesinger HJ, Glass GV. The effect of psychological intervention on recovery from surgery and heart attacks: an analysis of the literature. Am J Public Health [Internet]. 1982 [acesso 15 jan 2018];72(2):141-51. Disponível: https://bit.ly/2E6QxBQ 
24. UhImann RF, Inui TS, Pecoraro RE, Carter WB. Relationship of patient request fulfillment to compliance, glycemic control, and other health care outcomes in insulin-dependent diabetes. J Gen Inter Med [Internet]. 1988 [acesso 15 jan 2018];3(5):458-63. Disponível: https://bit.ly/2JFd9wQ

25. Brody DS, Miller SM, Lerman CE, Smith DG, Caputo GC. Patient perception of involvement in medical care: relationship to illness attitudes and outcomes. J Gen Intern Med [Internet]. 1989 [acesso 15 jan 2018];4(6):506-11. Disponível: https://bit.ly/2VrTF1f

26. Stewart M, Brown JB, Donner A, McWhinney IR, Oates J, Weston WW et al. The impact of patientcentered care on outcomes. J Fam Pract [Internet]. 2000 [acesso 15 jan 2018];49(9):796-804. Disponível: https://bit.ly/2Vo5wgD

27. Stewart MA. Effective physician-patient communication and health outcomes: a review. CMAJ [Internet]. 1995 [acesso 15 jan 2018];152(9):1423-33. Disponível: https://bit.ly/2E5sROg

28. Benware CA, Deci EL. Quality of learning with an active versus passive motivational set. Am Educ Res J [Internet]. 1984 [acesso 15 jan 2018];21(4):755-6. DOI: 10.3102/00028312021004755

29. Putnam AL, Sungkhasettee VW, Roediger HL III. Optimizing learning in college: tips from cognitive psychology. Perspect Psychol Sci [Internet]. 2016 [acesso 15 jan 2018];11(5):652-60. DOI: $10.1177 / 1745691616645770$

30. Michael J. Where's the evidence that active learning works? Adv Physiol Educ [Internet]. 2006 [acesso 15 jan 2018];30(4):159-67. DOI: 10.1152/advan.00053.2006

31. Lifchez SD, Redett RJ III. A standardized patient model to teach and assess professionalism and communication skills: the effect of personality type on performance. J Surg Educ [Internet]. 2014 [acesso 15 jan 2018];71(3):297-301. Disponível: https://bit.ly/2E9APGb

32. Arnold RM, Back AL, Barnato AE, Prendergast TJ, Emlet LL, Karpov I et al. The critical care communication project: improving fellows' communication skills. J Crit Care [Internet]. 2015 [acesso 15 jan 2018];30(2):250-4. Disponível: https://bit.ly/2LCPobo

33. Greenberg LW, Ochsenschlager D, O'Donnell R, Mastruserio J, Cohen GJ. Communicating bad news: a pediatric department's evaluation of a simulated intervention. Pediatrics [Internet]. 1999 [acesso 15 jan 2018];103(6 Pt 1):1210-7. Disponível: https://bit.ly/2HjdK5J

34. Ju M, Berman AT, Hwang WT, Lamarra D, Baffic C, Suneja G et al. Assessing interpersonal and communication skills in radiation oncology residents: a pilot standardized patient program. Int J Radiat Oncol Biol Phys [Internet]. 2014 [acesso 15 jan 2018];88(5):1129-35. Disponível: https://bit.ly/2E7IMNe

35. Colletti L, Gruppen L, Barclay M, Stern D. Teaching students to break bad news. Am J Surg [Internet]. 2001 [acesso 15 jan 2018];182(1):20-3. DOI: 10.1016/S0002-9610(01)00651-1

36. Dikici MF, Yaris F, Cubukcu M. Teaching medical students how to break bad news: a Turkish experience. J Cancer Educ [Internet]. 2009 [acesso 15 jan 2018];24(4):246-8. Disponível: https://bit.ly/2E74pw4

37. Ramaswamy R, Williams A, Clark EM, Kelley AS. Communication skills curriculum for foreign medical graduates in an internal medicine residency program. J Am Geriatr Soc [Internet]. 2014 [acesso 15 jan 2018];62(11):2153-8. DOI: 10.1111/jgs.13094

38. Vail L, Sandhu H, Fisher J, Cooke H, Dale J, Barnett M. Hospital consultants breaking bad news with simulated patients: an analysis of communication using the Roter Interaction Analysis System. Patient Educ Couns [Internet]. 2011 [acesso 15 jan 2018];83(2):185-94. Disponível: https://bit.ly/2LITT4r

39. Setubal MSV, Antonio MÂRGM, Amaral EM, Boulet J. Improving perinatology residents' skills in breaking bad news: a randomized intervention study. Rev Bras Ginecol Obstet [Internet]. 2018 [acesso 15 jan 2018];40(3):137-46. DOI: 10.1055/s-0037-1621741

40. Karam VY, Barakat $\mathrm{H}$, Aouad M, Harris I, Park YS, Youssef $\mathrm{N}$ et al. Effect of a simulation-based workshop on breaking bad news for anesthesiology residents: an intervention study. BMC Anesthesiol [Internet]. 2017 [acesso 15 jan 2018];17(1):77. Disponível: https://bit.ly/2HtRIwi

41. Cohen RA, Jackson VA, Norwich D, Schell JO, Schaefer K, Ship AN et al. A nephrology fellows' communication skills course: an educational quality improvement report. Am J Kidney Dis [Internet]. 2016 [acesso 15 jan 2018];68(2):203-11. Disponível: https://bit.ly/2Jk3Vqw

42. von Lengerke $\mathrm{T}$, Kursch $\mathrm{A}$, Lange $\mathrm{K}$. The communication skills course for second year medical students at Hannover Medical School: an evaluation study based on students' self-assessments. GMS J Med Educ [Internet]. 2011 [acesso 15 jan 2018];28(4):Doc54. Disponível: https://bit.ly/2YvFIAX

43. Abel J, Dennison S, Senior-Smith G, Dolley T, Lovett J, Cassidy S. Breaking bad news: development of a hospital-based training workshop. Lancet Oncol [Internet]. 2001 [acesso 15 jan 2018];2(6):380-4. Disponível: https://bit.ly/2HmGqK5

44. Alexander SC, Keitz SA, Sloane R, Tulsky JA. A controlled trial of a short course to improve residents' communication with patients at the end of life. Acad Med [Internet]. 2006 [acesso 15 jan 2018];81(11):1008-12. Disponível: https://bit.ly/2YrbP4T

45. Sombra Neto LL, Silva VLL, Lima CDC, Moura HTM, Gonçalves ALM, Pires APB et al. Habilidade de comunicação da má notícia: o estudante de medicina está preparado? Rev Bras Educ Méd [Internet]. 2017 [acesso 15 jan 2018];41(2):260-8. Disponível: https://bit.ly/2YJzM8y

46. Burn CL, Hurst SA, Ummel M, Cerutti B, Baroffio A. Telling the truth: medical students' progress with an ethical skill. Med Teach [Internet]. 2014 [acesso 15 jan 2018];36(3):251-9. DOI: 10.3109/0142159X.2013.853118

47. Hurst SA, Baroffio A, Ummel M, Burn CL. Helping medical students to acquire a deeper understanding of truth-telling. Med Educ Online [Internet]. 2015 [acesso 15 jan 2018];20(1):28133. DOI: $10.3402 /$ meo.v20.28133 
48. Skye EP, Wagenschutz $H$, Steiger JA, Kumagai AK. Use of interactive theater and role play to develop medical students' skills in breaking bad news. J Cancer Educ [Internet]. 2014 [acesso 15 jan 2018];29(4):704-8. Disponível: https://bit.ly/2JzS2fw

49. Parikh PP, White MT, Buckingham L, Tchorz KM. Evaluation of palliative care training and skills retention by medical students. J Surg Res [Internet]. 2017 [acesso 15 jan 2018];211:172-7. Disponível: https://bit.ly/2E9R06x

50. Ellman MS, Fortin AH VI. Benefits of teaching medical students how to communicate with patients having serious illness: comparison of two approaches to experiential, skill-based, and selfreflective learning. Yale J Biol Med [Internet]. 2012 [acesso 15 jan 2018];85(2):261-70. Disponível: https://bit.ly/2LFOAEs

51. Szmuilowicz E, el-Jawahri A, Chiappetta L, Kamdar M, Block S. Improving residents' end-of-life communication skills with a short retreat: a randomized controlled trial. J Palliat Med [Internet]. 2010 [acesso 15 jan 2018];13(4):439-52. Disponível: https://bit.ly/2WNG7yA

52. Brown SD, Callahan MJ, Browning DM, Lebowitz RL, Bell SK, Jang J et al. Radiology trainees' comfort with difficult conversations and attitudes about error disclosure: effect of a communication skills workshop. J Am Coll Radiol [Internet]. 2014 [acesso 15 jan 2018];11(8):781-7. Disponível: https://bit.ly/2LHt6oO

53. Levi BH, Green MJ. Humanities in full retreat. Teach Learn Med [Internet]. 2003 [acesso 15 jan 2018];15(4):252-6. Disponível: https://bit.ly/2W3aunp

54. Coutinho F, Ramessur A. An overview of teaching communication of bad news in medical school: should a lecture be adequate to address the topic? Acta Med Port [Internet]. 2016 [acesso 15 jan 2018];29(12):826-31. Disponível: https://bit.ly/2LEOfBP

55. Makoul G, Zick AB, Aakhus M, Neely KJ, Roemer PE. Using an online forum to encourage reflection about difficult conversations in medicine. Patient Educ Couns [Internet]. 2010 [acesso 15 jan 2018];79(1):83-6. Disponível: https://bit.ly/2WDMrbE

56. Lisle J, Teelucksingh S, Seemungal T, Mungrue K, Willimas S. Gender differentials on breaking bad news: implications for communication skills training in medical school. In: Steele GA, editor. Health communication in the Caribbean and beyond: a reader. Kingston: University of the West Indies Press; 2011. p. 21-43.

57. Quirk M, Mazor K, Haley HL, Philbin M, Fischer M, Sullivan K, Hatem D. How patients perceive a doctor's caring attitude. Patient Educ Couns [Internet]. 2008 [acesso 15 jan 2018];72(3):359-66. Disponível: https://bit.ly/2WHrpZV

58. Wheatley-Price P, Massey C, Panzarella T, Shepherd FA, Mikhael J. Resident preparedness in discussing prognosis in patients with advanced lung cancer. Support Care Cancer [Internet]. 2010 [acesso 15 jan 2018];18(4):491-7. Disponível: https://bit.ly/2Vog0wo

59. Hatem D, Mazor K, Fischer M, Philbin M, Quirk M. Applying patient perspectives on caring to curriculum development. Patient Educ Couns [Internet]. 2008 [acesso 15 jan 2018];72(3):367-73. Disponível: https://bit.ly/2JjPpyZ

\section{Participação dos autores}

Nicole Cavalari Camargo and Marcelo Gonçalves de Lima elaborated the systematic review and tables. Elisa Brietzke developed the final revision of the text. Samantha Mucci together with Aécio Flávio Teixeira de Góis supervised the project.

\section{Correspondência}

Nicole Cavalari Camargo - Rua Botucatu, 720, Vila Clementino CEP 04023-062. São Paulo/SP, Brasil.

Nicole Cavalari Camargo - Graduanda - nicole.cavalari@huhsp.org.br

(iD) 0000-0003-4999-3384

Marcelo Gonçalves de Lima - Graduando - lima.marcelog@gmail.com

(iD) 0000-0001-6742-5845

Elisa Brietzke - Doutora - elisabrietzke@hotmail.com

(iD) 0000-0003-2697-1342

Samantha Mucci - Doutora - sammucci@gmail.com

(D) 0000-0003-3809-8173

Aécio Flávio Teixeira de Góis - Doutor - aecio.gois@unifesp.br

(D) $0000-0003-0217-1463$ 